\title{
Larysa Klymanska*
}

Lviv Politechnic National University

\section{Iryna Boiko}

Lviv Politechnic National University

\section{AGEISM STEREOTYPING AS A SOCIAL POLICY PREMISE}

\begin{abstract}
This article deals with socio-cultural factors of the problems of "social status of older people". The aim of the paper is to analyze the socio-cultural values of elements of social gerontology in order to identify the factors that determine the basis for the formation of social policy of old age in modern society. We have indicated the basic attitudes and behaviours that affect the regulation of the social problem of the status of older people.
\end{abstract}

Keywords: ageism, social policy, social policy premise

The notable growth process of elderly people, coinciding with the worldwide trend of population aging, is accompanied by social problems which can be considered as a result of interactions between age groups in Ukrainian society and social policy courses. Competitiveness between age groups and changes in social status as a result of transformation processes have given rise to so-called social distance, which indicates feelings of social differences in status positions. The need to adopt social policy courses appropriate to the situation is sometimes caused not only by economic and demographic factors, but also by the system of cultural values.

The level of civilization of a modern society is largely determined by the social well-being of the older generation. Social conditioning of a lifetime has become so obvious today that it supplants all other aspects of the problem. In all modern countries there is a problem that can be conditionally called the "social status of older people". It has two components: the objective tendencies of an "aging population" and the subjective desire to resolve this problem in various versions of social policy. There is usually a sociocultural "cushion" between the first and second parts of this problem that softens or creates more strict conditions for the implementation of such a social policy. Social and cultural factors that determine policies for older people in the community may be considered under the scheme of: stereotypes - behaviours - social policy.

\footnotetext{
* Corresponding author: Larysa Klymanska, Galytska 19/11-A, Lviv; e-mail: larysa_kl@ukr.net.
} 
An aging population is long-term in nature. In Ukraine, the number of older people is about $24 \%$ of the population. According to the State Statistics Committee of Ukraine, every fifth citizen is a person of advanced age, and one in six of those are single people. Half of the single people need help in everyday life, especially today when many retirees' main source of income is a pension, the amount of which does not provide for an adequate standard of living in Ukraine. Over $80 \%$ of them are forced to live below the poverty line, receiving a pension under 1,108 UAH, which is not enough to ensure a decent quality of life (Rozmova... 2013). In recent years the topic of Ukraine's aging population increased, social problems of the elderly are rather clearly marked by official agencies, by representatives of academic community. Meanwhile, in Ukraine a modern-state social policy has not been formed, one that would express attitudes towards the elderly as a substantial socio-demographic group that can actively influence the socio-economic development of the country.

The United Nations has been considering issues of social policy towards the elderly since 1948, when a prior declaration on the rights of older people was drafted. In 1982 the World Assembly on Ageing was convened. The adoption of the Vienna International Plan of Action on Ageing was a consequence of this assembly. Its primary objectives were to expand capacity to effectively tackle the problems associated with an aging population and meet the needs of older people. However, since the adoption of the Vienna Plan of Action on Ageing the situation in the world has changed dramatically. The aging of society is gradually becoming a global phenomenon. The "epicenter" of demographic aging has shifted to developing countries (Regional Dimensions 2008).

These factors have led to the United Nations Second World Assembly on Aging (Madrid 2002), where the process of demographic aging and its value to society was equated with the process of globalization. The Madrid International Plan of Action on Aging was adopted at this assembly, according to which a society for all ages will be the main objective of policies and programs on aging. Such a UN definition refers to a society in which different generations contribute to their common development on the basis of dual reciprocity and fairness in relations between different generations (Novyny mista).

In Madrid, governments of UN member states agreed that their action on aging at the national and international levels would be implemented in three priority areas: older people and the society; health and well-being in old age; and conditions that contribute to individual human development and support of this development throughout life. The Madrid Plan is a global strategy in which governments pledged to compare the direction and content of action on aging at the national level.

These international instruments developed under the United Nations are contained in a declarative document of a recommendatory nature. One of the recent international instruments on seniors' human rights mentioned above - the Madrid International Plan on Ageing - is not considered by Ukraine. Problems of older people are solved by the Ukrainian state only partially and inconsistently. Ukraine does have a law "On Fundamentals of Social Security of Veterans of Labour and Seniors in Ukraine" (Pro osnovni zasady... 1993).

Legislation is designed to contribute to support elderly people and their return to independent living. But often in the real life problems of older people are overlooked by society or resolved formally. 
Ageism stereotyping as a social policy premise

The process of aging of the population in Ukraine coincided with a period of social transformation, which has worsened the situation for the elderly, dramatically exacerbating the problem of lack of demand for this category of citizens, which leads to their exclusion from the scope of economic activity and active cultural and social life. The framework of social policy is reduced to evaluation and adjustment of costs for social security of retirees. The potential of these people, including their potential positive influence on the younger and middle age groups, is almost completely overlooked.

The current situation with the elderly in Ukraine demands that the public overcome intolerance and ageist attitudes towards the elderly, to foster a culture of tolerance, develop philosophical systems of "integrated age", and form a "society for all ages", based on the principles of interdependence, reciprocity and fairness. Radical revision of the position of the state in relation to older people involves not only enhancing of protective functions for them, but also activating them in social life as far as possible .

Consequently, in modern Ukraine there is a need for adoption of social programs that would reflect global trends in attitudes towards older people and solve their problems on the national level.

This task is impossible to perform without a legal basis for interaction between the age group and society. Social policy of a state is expressed primarily in regulatory and legal framework. In return, the primary analysis of legislation clearly demonstrates the stereotypical or "categorical" approach of legislators to accept retirees. "Senior" in Ukraine is a category of citizen in terms of legislation that automatically equates to the categories of "poor" and "disabled". In a great number of documents this category of citizens is listed as recipients with an asterisk. The terms "disabled" and "seniors" are used in parallel, denoting categories of people with similar needs. Sometimes the "retired" are indicated within the broader category of "low income". Thus, legislation is virtually impossible for a potential field of healthy, active seniors.

The majority of legislative acts constitute documents of the most common formulation: quality of life and social support. Some of them are intended to clearly highlight direct cash benefits (pension supplements, material assistance), as well as non-monetary benefits (such as the allocation of food packages). Analysis of these legal acts shows a definite pattern.

The most important and priority of social policy for the elderly in all the documents is to increase material wealth, as more than $30 \%$ of them (this documents - legislative acts) are directly related to the establishment of direct financial benefits. Again, in the budget proposals for 2014 from the Federation of Trade Unions of Ukraine it was declared: “... to allocate funds to finance in full the state guarantees to provide social benefits and compensation to veterans, veterans of labour, invalids of all categories, persons belonging to Victims of Nazi Persecution and other beneficiaries; to improve the social protection of the poor and social services to the elderly, disabled..." (Rozmova... 2013).

Among the legal acts one can identify those that promote the participation of older people in social events, and promote respect for this category of the population in the community and its inclusion in society. It should be noted that unfortunately most of these legal acts are associated with the celebration of Victory Day, activities within the celebration of the International Day of Older Persons. 
So, we can say that the regulatory framework of this social problem is still far from the current requirements of the international community. The Legislature should look at all aspects of the quality of life of an older person, not only at improving financial conditions (as it is described in the Madrid Plan of Action on Aging).

Another direction in solving social problems of the "social status of older people" can be considered as forming a conscious awareness of the need for the development of national-level policy on aging. In realizing this task, society can rely on the basic elements of gerontological culture. Scientists interpret gerontological culture as a set of specific principles of life, attitudes towards older people and older people to life, to society, to themselves. Gerontological culture is a kind of philosophy of life and aging (Suhobskaya 1998).

Gerontological culture as a kind of subculture includes a set of values. First of all are the values that exist in society and depend on cultural and historical features of a particular society. They are fixed in the public consciousness in the form of proverbs, and appear in the actual policies pursued by the government in relation to older people, for example, in establishing the age norms of retirement. They are found in the real, rather than declared, benefits, in social programs oriented to the age category of people, and even in the semantics of words which refer to the older generation. The very words "retirement" and "elderly" carry negative semantic meanings, which is reflected in the minds of most older people and the attitude of younger segments of the population towards them. Germans, for example, do not call the older people "old people" or even "third age ", they are respectfully called Senioren (respected). Perhaps that is why in one of the publications devoted to the International Day of Older Persons in Ukraine October 1, 2013 the author proposed referring to old people as "mature old age people" (Novyny).

An important element of gerontological culture is the formation of social attitudes towards older people. These attitudes vary depending on economic conditions and dominant values. In the early period of civilization the most respected period of life was the period of maturity on the basis that the person had rich enough experience in obtaining food (fruit picking, fishing, hunting etc.), so such a person was looked upon as a teacher, who transferred their knowledge and secrets to younger people. Many Eastern cultures treated age with respect, because it primarily saw older age as wisdom, as an age of "understanding of their own mistakes and lessons learned". In the Eastern idea of reincarnation they observe a cyclical approach to life - everything returns to normal. In this system, notions of old age turns out to be summarizing of the intermediate time in the development of outer life. It was believed that during this period the person is closer to eternity than at any time in their lives (Volyinskaya 2000).

A.H. Levinson gives an example of the opposite attitude to older people in agrarian societies where there was a tradition of artificial termination of life of older people. "Killing had nothing to do with the crime of greed or killing enemies. The relocation of elderly people to the country of their ancestors was firmly secured with ritual and mythological interpretations within the context of spring renewal of nature" (Levinson 2005).

The elderly have held a wide range of status positions within the state throughout human history, from the duty-killing of elderly parents to the gerontocracy that existed in Ancient Greece. Modern society is not fully determined in its position. There are two well-known, 
inherently contradictory images of older people: positive (the venerable sage with a gray beard and a wealth of experience) and negative (an emaciated old man). However, society's attitude towards an aging generation depends on a multitude of practical problems, in particular on the nature and the direction of social policy. For example, society must decide whether social policy should be directed to continue the activity of aging people or to ensure a quiet, passive old age. Equally important is the question of whether society should encourage the formation of gerontological culture or, conversely, not emphasizing the specificity of aging, but focusing on the fact that older people are first and foremost adults.

In modern society the situation is such that the position of the majority of older people has deteriorated. This can be explained partly by the fact that our society has a negative portrait of an the elderly as unnecessary, aggravating and passive. The discourse of social problems often becomes their source; in particular, the discourse can be a source of stereotypical attitudes. It is therefore important to analyze the attitudes and stereotypes of aging as one of the factors that affects the self-esteem of the elderly person, the level of social claims and, ultimately, the position of the individual as a subject or an object in a social interaction.

To describe contemptuously indifferent attitudes to the elderly, the term "ageism" was introduced by American researcher R. Butler (Butler 1969). All societies use age and sex to classify their members, and they have different expectations for each category. Despite the age-old culture of respect for the older generation in Ukraine, a set of prejudices and discriminations against our elders is being established.

Ageism has been called the ultimate prejudice, the last discrimination, the crudest rejection. The prejudices range from the stereotype that most are senile to the assumption that they have no need for sexual gratification. The discriminations range from forced retirement to elder abuse. Racism became a burning issue in the 19th century and was attacked by the abolitionist and civil rights movements. Sexism became a burning issue in the 20th century and was attacked by the suffrage and equal rights movements. Ageism is the third great "ism" of modern society. It is now being attacked by gerontologists and the aged themselves.

Ageism is a prejudice against older people because they are old. Like other 'aisms', such as racism, it lumps a large group of people together and reduces them to a negative common denominator. Ageism is extremely pervasive and permeates many aspects of society including government, the general public, and older people themselves.

Ageism involves the perception of older people as intellectually untenable and oldfashioned in their views. Ageism has been called the bias that gives rise to discrimination. Ageist attitudes are extremely common and manifest themselves in many aspects of society. At the institutional level, it can be legally enshrined as discrimination against people of a particular age group; at the interpersonal level it comes as insulting, degrading acts that include negative interpersonal interactions initiated by the younger generation with regard to the elderly, and disparaging remarks about aging and older people; and through existing beliefs in modern society, based not on an actual facts, but on outdated notions about the period of late adulthood only as chronological regression and decline.

It is believed that the inherent traits of the elderly are negativism, conservatism, inertia, stubbornness, ill-temper, increased vulnerability, selfishness, irritability, pettiness, avarice, 
and others. Along with these descriptive stereotypes there are still so-called "prescriptive stereotypes" that summarize information about how older people are to behave, and this often leads to discriminatory behavior and practices. Prescriptive stereotypes focus on three central issues:

- continuity, namely the idea that older people have to free up space for young people and do not require well-paid jobs or prominent social roles,

- identity, namely the idea that older people should not try to behave so as to appear younger than they are,

- consumption, namely the idea that older people should not consume so many scarce resources, especially in the health sector.

Ageist behaviour that indirectly affects social policy arises from stereotypes and negative attitudes. Behavioral ageism in practice is behaviour that discriminates against people on the basis of chronological age. This behaviour may vary from passive to aggressive forms of interaction with older people. The most obvious form of this behavior can be called "patronizing language" with two main types: overaccommodation and baby talk.

Overaccommodation involves excessive politeness, increased tone of voice and slowness of speech and simple sentences with older people (Giles 1993). It is based on the stereotype that older people have hearing problems, decreased intelligence, and slowing of cognitive functions. A discriminatory conversation called "baby talk" includes "simplified registration language with high notes and exaggerated intonation”. As a specific type of speech baby talk is used to talk to babies (the primary language for children), often in "conversation "with pets, inanimate objects, and in dealing with older people, 'creating an atmosphere of dependency. Using this type of speech is probably related to the stereotype that all older people have deficits in cognitive abilities, and thus require special communication at a slow, easy level.

Non-verbal ageist practices can range from indifference or neglect of the elderly by a micro social group or its individual members, to indirect or direct violence against them, such as restrictions of legal, labour and civil rights of the elderly; violation of permissible limits in pharmacotherapy; neglect in caring for older people, which can cause physical or mental injury; passive attitudes to the disease process or dying; social aggression; psychological terror; economic abuse; forced isolation; deprivation of sleep or rest; deprivation of food and/ or water; direct use of physical force; denial of necessary treatment or medical care (passive euthanasia); and murder.

Thus, in today's society there is a social problem conventionally designated as "social status of older people", due to a number of objective and subjective factors. Overcoming discrimination against older people is today an extremely important and necessary task for any society, including Ukraine. Resolution of this problem requires efforts not only at the national level. The process of settling of social problems involves many actors who can both "problematize" and "deproblematize" difficult social circumstances. Further exploration in this area could include a study of the role of non-governmental organizations, the media, the views of experts in the evaluation of the status of older people and overcoming ageism, and construction of old age in the rhetoric and practice of social policy. 


\section{REFERENCES}

Rozmova z Yuriyem Kulykom, Holovoyu FPU. 2013. http://wInter'ww.psv.org.ua/arts/intervyu/ view-1821.html [31.01.2014].

Giles, Howard, Susan Fox and Elisa Smith. 1993. Patronizing the elderly: Intergenerational evaluations, "Research on Language and Social Interaction" 26(2): 129-149.

Levinson, Aleksey. 2005. Starost' kak institut, "Otechestvennyie Zapiski” 3, http://www. strana-oz.ru/?numid=24\&article=1061 [03.01.2014].

Novyny mista: Sergiy Krushanovskiy: "Na moe gliboke perekonannya-ne mae lyudey pohiloho viku, e lyudi povazhnogo viku", http://darn.kievcity.gov.ua/news/1191.html [02.02.2014].

Pro osnovni zasady sotsial'noho zakhystu veteraniv pratsi ta inshykh hromadyan pokhyloho viku v Ukrayini, 1993. Zakon Ukrayiny No 372-III vid 16.12.1993, http://www.rada.dov. ua/cgi-bin/laws/main.cgi [04.02.2014].

Regional Dimensions of Ageing Situation. 2008. "Economic and Social Affairs UN/NY", p. 5, http://undesadspd.org/LinkClick.aspx?fileticket=E0b_uwzSjY8\%3D\&tabid=502 [02.02.2014].

Suhobskaya, Galina and Natalya M. Bozhko. 1998. Pozhiloy chelovek v sovremennom mire: Posobie dlya sotsialnyih pedagogov, Petersburg: Tuskarora.

Volyinskaya Lyudmila B. 2000. Prestizhnost vozrasta, „Sotsiologicheskie Issledovaniya” 7: $120-124$.

Butler, Robert N. 1969. Ageism: Another form of bigotry, "The Gerontologist" (9): 243-246.

\section{STEREOTYPY ZWIĄZANE Z WIEKIEM A ZAŁOŻENIA POLITYKI SPOŁECZNEJ}

Artykuł porusza zagadnienia społeczno-kulturowych czynników determinujących status społeczny osób starszych. Jego celem jest analiza wpływu tych czynników na założenia polityki społecznej w zakresie starzenia się współczesnych społeczeństw z perspektywy gerontologii społecznej oraz wskazanie podstawowych postaw i zachowań, które wytyczają kierunki kształtowanej polityki społecznej związanej z problemami osób starszych.

Słowa kluczowe: ageizm, polityka społeczna, założenia polityki społecznej 